\title{
The economic potential of the brics countries as a challenge to modern world realities
}

\section{O potencial econômico dos países brics como um desafio às realidades do mundo moderno}

\author{
Evgeny Sergeevich Streltsov \\ Pskov State University Address: 180000, Pskov, Lenin Square, 2 \\ ORCID: 0000-0002-8422-3484
}

\begin{abstract}
Aleksandr Aleksandrovich Rozhin
The Institute of Europe of the Russian Academy of Sciences, Address: 11-3, Mokhovaya street, 125009, Moscow, Russia

ORCID: 0000-0003-0714-865X
\end{abstract}

\section{Sh. S. Vosiev}

Reshetnev Siberian State University of Science and Technology 31 "KrasnoyarskiyRabochiy" pr.,

Krasnoyarsk, 660014, Russia

ORCID: 0000-0003-0652-1125

\section{Sergey Nikolaevich Kosnikov}

Kuban State Agrarin University named after I.T. Trubilin, 350044, Russian Federation, Krasnodar Krai, Krasnodar city, Kalinina St. 13

ORCID: 0000-0002-2918-8209

Received 09-08-20 Revised 10-10-20

* Correspondence

Email: strelczov.e@bk.ru

\section{Accepted 12-12-20 On line 03-15-21}

\section{Citation:}

Evgeny Sergeevich Streltsov, Aleksandr Aleksandrovich Rozhin, Sh. S. Vosiev, Sergey Nikolaevich Kosnikov. (2021). Research on Meeting the Demand of the Population for A Group of Medicines Intended for the Treatment of Skin Diseases. Propósitos $y$ Representaciones, 9 (SPE3), e1143. Doi: http://dx.doi.org/10.20511/pyr2021.v9nSPE3.1143 


\begin{abstract}
Today, the governments of various countries, regardless of the level of economic growth of the state, strive to initiate macroeconomic policies aimed at achieving better economic indicators in order to increase the level of business activity and, finally, to ensure a better quality of life for people. In this regard, the policy of the BRICS countries is very indicative. The author analyzes the importance of the BRICS group as representatives of developing countries in the world economy. The article points out that the financial crisis did not have a strong impact on the BRICS group, and its economic performance was much better than that of developed countries. The main factors that led to the economic expansion of the group were the increased influence in a number of markets, as well as the huge scale of resources, including labor. For example, Brazil and Russia rely mainly on huge mineral reserves and speculation in international markets. China has the advantage of cheap labor and resources at low prices. India also relies on cheap labor. Last but not least, all the BRICS countries, except Brazil, demonstrate very high rates of investment. The purpose of the work is to consider the economic potential of the BRICS countries as a challenge to modern economic realities. Key words: economic potential, the world economy, the BRICS countries.
\end{abstract}

\title{
Resumen
}

Hoy, los gobiernos de varios países, independientemente del nivel de crecimiento económico del estado, se esfuerzan por iniciar políticas macroeconómicas encaminadas a lograr mejores indicadores económicos con el fin de incrementar el nivel de actividad empresarial y, finalmente, asegurar una mejor calidad de vida. para la gente. En este sentido, la política de los países BRICS es muy indicativa. El autor analiza la importancia del grupo BRICS como representantes de los países en desarrollo en la economía mundial. El artículo señala que la crisis financiera no tuvo un fuerte impacto en el grupo BRICS, y su desempeño económico fue mucho mejor que el de los países desarrollados. Los principales factores que llevaron a la expansión económica del grupo fueron la mayor influencia en varios mercados, así como la enorme escala de recursos, incluida la mano de obra. Por ejemplo, Brasil y Rusia dependen principalmente de enormes reservas minerales y de la especulación en los mercados internacionales. China tiene la ventaja de contar con mano de obra y recursos baratos a precios bajos. India también depende de la mano de obra barata. Por último, pero no menos importante, todos los países BRICS, excepto Brasil, presentan tasas de inversión muy elevadas. El propósito del trabajo es considerar el potencial económico de los países BRICS como un desafío a las realidades económicas modernas.

Palabras clave: potencial económico, economía mundial, países BRICS.

\section{Introduction.}

In the recent period, developing countries have played an important role on the world stage, especially in the context of the financial crisis. In this sense, they represent an important force for the recovery of the world economy, as noted by a number of researchers.

The reorganization of the world economy and the change in global influence are based on the rise of the great Powers. In the last decade, developing countries in the economic context have had much higher growth rates compared to developed countries, which has led to a significant increase in their share of world GDP in international trade, in the total volume of foreign direct investment [1].

During this period, an important role was played by the BRICS countries (Brazil, Russia, India, China, South Africa), which have several similar features:

- these are developing countries with corresponding global economic indicators and high potential;

- these are countries of systemic importance to the world economy; in this respect, their national performance has profound implications at both the regional and global levels;

- these countries are able to influence the management of the world economy [2].

All these features, together with a number of common interests, show that the BRICS countries have formed as a coalition of developing countries, where government representatives have a certain weight in decision-making at the international level. However, it should be noted that there are important differences in the four countries in terms of production structure by sector, export 
opening, exchange rate regime, etc., which makes this coalition a more ambitious project. China has much more economic power than other BRICS countries.

The BRICS countries have focused on their growing economic power and development to create an agency to compete with the World Bank. In this regard, the member countries have signed several trade agreements on the extensive use of local currencies on their commercial exchanges, the main purpose of which is to reduce transaction costs [3].

The aim of the paper is to consider the economic potential of the BRICS countries as a challenge to modern economic realities.

Materials and methods. In the process of writing the paper, the literature on the research topic related to the economic potential of the BRICS countries was analyzed. Analytical, comparative, and comparative methods were also used in writing.

Results. As you know, developing countries are concentrated in the regions with the largest population in the world. At the beginning of the century, their image underwent a radical change due to the most dynamic growth in the world and a decline in population growth, which led to GDP per capita growth close to the level of developed countries. This was made possible by the increasing degree of economic integration of developing countries into the world economy, which materialized in the trade and financial sector. The favorable prospects for these countries have led to a reduction in the perception of risks from emerging markets and the consolidation of the above-mentioned trends [4]. The BRICS countries are among those developing countries that have the characteristics listed above.

The economies of the BRICS group developed through a number of policy initiatives that were firmly focused on the tools of the import substitution industrialization (ISI) policy, including high tariffs, subsidies, targeted import controls and, ultimately, an export-oriented strategy.

The ISI policy initiative has received various criticisms over the past decades. This policy initiative was (and still is) criticized by some neoliberal advocates more prominently in the 1970s and 1980s. [5]

Global organizations, especially the Bretton Woods Agreement with institutions (the International Monetary Fund-the IMF and the World Bank), and politicians, especially Western hegemons, were part of this persecution. The term Washington Consensus, coined in 1989 by John Williamson, became the basis of the political prescriptions of neoliberal / neoclassical ideologues, hence its disapproval and antipathy from the left, who view politics as an ornament to imperialism rather than as a diagnosis of economic problems. Contrary to what axiomatically neoclassical theory considered a methodological masterpiece, neoliberal ideology challenged the economic path that has led hitherto underdeveloped countries (today's economic centers) to the present reward [6].

The ISI policy, which was adopted early in the struggle for industrialization in most developing countries, emerged during the evolutionary stages of industrialization in advanced economies: "The growth of import substitution industrialization has been accompanied by doubts about its continued viability to support economic growth, paradoxically, in countries that have already achieved a high degree of industrialization. These industrialized countries are thought to have an ISI architecture, and it becomes ironic to discover the dexterity with which they rewrite their economic history, suggesting that economic development and, indeed, industrialization can only be achieved through neoliberalism or neoclassical ideology.

Almost all of today's rich countries used tariff protection and subsidies to develop their industries at an early stage of their development. It is particularly important to note that the United Kingdom and the United States, the two countries that are supposed to have reached the top of the world economy through free-market and free-trade policies, are actually the countries that have used protection and subsidies most aggressively.

The documented evidence points to the time frame during which each of these advanced economies applied ISI at the stages of their development. For example, the United Kingdom ended its protectionist policy only in 1846, repealing the human trafficking laws that accelerated the country's industrialization process. It was also found that ISI was adopted in the United States, and this policy was institutionalized through various protectionist measures.

ISI's industrial policy is based on the realization that economic development, and in particular industrialization, can only be achieved by developing local capacity to replace imports in order to reduce or possibly eliminate economic leakage. This policy became popular in today's developing countries shortly after World War II, mainly because production resources were diverted from home production to military weapons during the war by developed countries, and the cost of 
living soared shortly after the war, putting pressure on the developing countries ' meager foreign reserves.

The second driving force behind this policy was the global economic crisis, which affected commodity prices, which accounted for (and still account for) the bulk of developing countries ' exports. According to the researchers, low demand and inelastic supply will constantly lead to lower commodity prices, on which the economies of most developing countries depend, which entails the need for material enrichment in order to eventually increase exports. However, no economy can export manufactured goods without creating the local infrastructure necessary for such production [7].

Moreover, ISI is seen as a catalyst for achieving economic diversification. Data from industrialized countries show that economic diversification is achievable through ISI policies. Thus, the mechanisms involved in the implementation of these policies (reduced tariffs on inputs, high import duties or locally produced goods, exchange rate differences and the possible elimination of export duties) help developing countries to gain the necessary industrial experience to start exporting manufactured goods competitively.

Based on the above, it becomes necessary for developing countries to be forced to adopt policy initiatives that would encourage the enrichment of materials in the face of global competition - hence, this was the justification for adopting ISI policies at an early stage of their industrialization. The argument for economic diversification is also supported by the adoption of ISI policies by developing countries. In particular, in order to diversify the economy, it is important to start developing local capacity or, more appropriately, strengthening local technological capacity. To achieve this, decisive State intervention and some form of protectionism are unavoidable.

The political intervention of ISI was accepted by all the BRICS countries at different stages of their industrialization. While all five countries have benefited significantly from the adoption of these policy instruments, the level of benefits received by each country varies significantly.

The ISI policy in Brazil dates back to $1930-\mathrm{m}$ to years, especially during the reign of President Getulio of Dornelles Vargas. President Vargas ruled Brazil between 1930 and 1954. During his tenure, he institutionalized local technological and industrial development and initiated policies aimed at increasing agricultural income and ultimately making efficient use of agricultural surplus. President Vargas was able to establish a proper link between the agricultural sector and production, which led to the efficient and effective use of agricultural rents to stimulate the initial process of industrialization of the country. The president's desire to create his own potential eventually led to the creation of the state oil corporation, Petrobras Brazilian, in 1953.

President Juscelino Kubicek came to power in 1954 and ruled until 1961. During his regime, he relied on the state's industrialization potential created by ISI policies and promoted exports in targeted industries. ISI policy remained unchanged, including various tariffs, duties and taxes, while export incentives were promoted by government incentives-subsidies. The period between 1962 and 1968 was characterized by various uncertainties and economic instability, and there were no clear economic achievements until President Emilio de ' Medici came to power in 1969 and ruled until 1974. [8]

The regime of President de ' Medici was considered the most successful regime in Brazil, not only in terms of achieving macroeconomic policies, but also in terms of social prosperity. The period from 1968 to 1973 was simply called the "Brazilian miracle" period. During this period, the Medici reduced the incentives for import substitution and stimulated the export of manufactured goods. He redirected the political focus from light to medium industry to heavy industry (machinery and heavy equipment). This intervention to diversify the economy bore immediate fruit, as the tax to-GDP ratio increased dramatically. This boost has boosted investor confidence in the economy, and the country has suddenly become juicy to whet the appetite of global financial investors. This event exposed Brazil to an unprecedented financial crisis that almost led to an economic crisis. However, Brazil's ability to weather the storm of challenges posed by economic openness (liberalism) and still become one of the fastest-growing economies depends on the institutional capacity that the country has built during ISI regimes.

The adoption of ISI policy in Russia follows the same well-thought-out line as Western history. The process of industrialization began in Russia, although relatively slowly, around the mid1880s. The slowdown in the process of industrialization in Russia was caused by the institutional restriction of Russian youth to arable land due to its use in the manufacturing industry (serfdom), contrary to the experience of industrialization in Germany and Austria. However, the country was 
able to turn the tide in 1861 , when the policy of serfdom was abolished, and young people were freed from industrial activities.

Periods after the abolition of serfdom did not lead to sporadic growth in industrialization until the mid-1860s, when the growth of railway construction became a driver of growth. To ensure accountability in the state's rapidly growing tax base, the government has reformed most national institutions, including the Treasury and the financial market. A massive reorientation was also carried out in an attempt to eradicate public distrust of the banking system and financial institutions in general. Understanding the contribution of agriculture to the rapidly developing Russian economy, the government supported the expansion wars against Western European countries. Fueling the war required the country to expand its military competence, which at one time equaled (and in some respects surpassed) the capabilities of the United States.

With the coming to power of President Vladimir Putin in 2000, some mechanisms of state intervention were restored, and the modern Russian economy is much more secure than the economy of most countries in the developing world. Some lessons have been learned from the collapse of the Soviet Union, which explains why Russia has re-adopted a quasi-ISI policy that primarily stimulated rapid industrialization by reintroducing protectionist measures within the export-oriented paradigm. It should also be noted that Russia's rise to the rank of industrialization was reinforced by the country's rich resources, which brought it a comparative advantage in many productive sectors, especially in the development of heavy industry (such as railways, agriculture, etc.). competent human capital). Thus, it is reasonable to conclude that Russia has received a huge benefit, both economically and militarily, thanks to the policy of the Ministry of Internal Affairs. In particular, Russia increased its military and economic potential, which allowed the Russian Federation to achieve global economic progress and political significance [9].

The experience of Indian ISI was no different from that of the other BRICS countries. The understanding of the development of Indian economic policy can best be divided into four periods, namely, the period from 1947 to 1956, from 1957 to 1960, from 1961 to 1965, and from 1966 to the present. The first two periods were characterized by the usual post-independence uncertainty and political vicissitudes. While disgust at the pre-independence hegemony of British business in the country influenced policy directions, the lack of support from local tycoons, as well as the financial / economic crises the country experienced during this period, also presented a particular problem.

A series of conflicting claims is reflected in the 1948 report of the Economic Program Committee (EPC), which proposed a nationalist political ideology underlying the socialist economic system. The committee's report reserved a vast chunk of the economy, from the production of consumables to cottage industry, banking, finance and insurance policies, and utilities. In particular, the main objective of the industrialization strategy was to develop local capacity in heavy industry, including the machine-building sector.

After a series of political vicissitudes, there has been a notable overhaul of ISI in India. The general lack of political orientation that characterized the first years after independence was replaced in 1966 by clear leadership, specific industrial goals and priorities under the auspices of the Second Industrialization Plan. The new policy was strictly aimed at expanding the sector of consumer goods with the help of policy instruments ISI. The main principle of this policy decision was the creation of an oligopolistic market structure capable of expanding the export base of the economy by restraining imports [10].

The liberalization efforts initiated in the late sixties eventually paid dividends as domestic consumption expanded, and this expansion led to further growth and local capacity building in other sectors, especially in heavy industry. India's ability to extend its import substitution from consumables to heavy industry has further helped the country achieve swadeshi's goals as local capacity develops and local technological competence advances. It is then reasonable to conclude that the ISI policy was successful in India because the country was able to " gradually extend import substitution to intermediate and capital goods." It is becoming clear that the ISI policy has helped India in the development of the automotive industry, information and communication technologies, and has also served as a catalyst for the country's export promotion program.

As for China, in the recent past, it boasted a booming economy with unprecedented levels of industrialization and poverty reduction. Despite global financial and economic instability, the Chinese economy remains the largest recipient of foreign capital inflows (especially, FDI) in the amount of US \$ 124 billion, of which the flow of capital to the service sector exceeded the flow of capital to the manufacturing sector. 
Evidence suggests that China's current economic power is based on the country's unique macroeconomic policy initiative, which was adopted between 1950 and 1995. This policy was based on a balanced comparison of two development models - Mao's closed economy (ISI) and Deng Xiao Ping's approach to economic liberalization (export-oriented industrialization - EOI). China followed the path of the rest of the communist states mainly from the early 1950s to the late 1970s, but with a unique taste of liberalization, dubbed "market socialism with Chinese characteristics".

Although the regime has adopted ISI as the main macroeconomic springboard, efforts have been made to simultaneously promote exports. The main constraint on the path to a free market economy was based on those goods that were considered important for social stability (such as oil, electricity, and water), and these sectors were largely dependent on the whims and whims of the regulatory framework. Today, the government still strictly regulates these basic services.

The ISI experience in South Africa is similar to that of Brazil, albeit with country-specific considerations. South Africa's economy is based on the political history that gave rise to its economic philosophy. In living history, South Africa is the only country where a full-fledged political ideology of apartheid has been embodied for decades. In this regard, some understanding of South Africa's political history is needed to nuance the dynamics of the country's macroeconomic policies.

Because of the inherent problems associated with apartheid, especially global isolation, Prime Minister Forster, who ruled South Africa from 1966 to 1978, strengthened ISI's economic policies as part of his industrial strategy, which was designed to reduce South Africa's dependence on foreign suppliers. strategic goods. This was achieved through the implementation of the following ISI-related initiatives:

- a large subsidy was provided for the organization of import substitution;

- large subsidies were provided for industrial development in the border areas of the country

These interventions were not enough to prevent the impending economic collapse, deepening economic crises and capital flight resulting from the alienation of multinational corporations and continuing political tensions. This disaster, among other things, led to the transition to a non-racial democracy in 1994.

Political and economic history took on a new dimension after the country's political liberation in 1994. After readmission to the world economic community, the country has adopted a number of economic reforms that are able to provide access to global markets and capital, as required by the institutions. The Washington Consensus. This macroeconomic policy was aimed at liberalizing the economy for foreign competition, tight fiscal and monetary policies, privatizing state assets, and liberalizing the labor market. In particular, the post-apartheid era in South Africa was characterized by an open market economy that took over all the remnants of export-oriented industrialization. It is then reasonable to assume that ISI has helped develop South Africa's mining sector, supported the production of energy and electricity to fuel the economy, and transformed the country's military capabilities as a result of its extensive participation in world trade.

We can say that the BRICS countries in recent years have demonstrated a model of economic growth that has a global impact. The BRICS exercise power as a group, not individually, thanks to their resources, territory, and population on a large scale. There are several elements that characterize the evolution of this group, namely:

- rapid economic growth was based on a massive supply of factors of production at very low prices. China relies on cheap labor and resources at low prices. India follows the Chinese model in terms of labor, while Russia and Brazil have huge advantages over natural resource reserves and international market speculation.;

- The BRIC countries have low indicators in terms of contribution to science and technology, because they do not have too much innovation;

- The economic growth of Brazil, South Africa, India and Russia is largely dependent on domestic demand, most of which is accounted for by consumption. In Brazil, consumption accounts for $80 \%$ of GDP, while external demand is only $2-3 \%$ [12].

Compared to other developing countries, Brazil has a lower level of investment (at least $20 \%$ ) due to the high level of real interest rates, fees and investment costs. In 2007, the government launched a PAC (la Programa de Aceleracao do Crescimento) aimed at increasing the investment rate to $25 \%$. 
As in Brazil, in India, development is largely dependent on domestic demand, where consumption plays an important role (50\% of GDP). In Russia, consumption accounts for $60-70 \%$ of GDP, investment-20\%, net exports-10\%;

- The BRICS countries have an unbalanced economic structure. The average level of the private sector in the economy is almost 50\% lower than the average in developed countries. BRICS is based mainly on the commodity sectors and is highly dependent on foreign markets [13].

The BRICS countries have significantly integrated into the financial sector, the main driver of which is direct investment. While developed countries generated the largest capital inflows and outflows in the 1990s, foreign direct investment in these countries increased by $14.8 \%$ at the beginning of the 21 st century. The role of the BRICS in this evolution was relevant, as almost half of the direct investment inflows into emerging economies led to this group.

Already in 2009, China became the second recipient of direct investment after the United States, and Russia ranked sixth. In addition, as private equity issuers, China and Russia ranked 11th and 12th in the world, ahead of countries such as Switzerland, Italy and the Netherlands. This trend had an increasing trend until 2016, after which it went down due to the growth of crisis situations in the economy.

Currently, there are some restrictions related to trade, finance, exchange rates of the BRICS countries, etc. For example, the depreciation of the dollar can lead to large losses for the BRICS countries, since they hold more than $60 \%$ of their reserves in dollars.

Cooperation between the BRICS countries is quite close, but at the same time they are in constant competition for the conquest of markets. Therefore, cooperation and competition between the BRICS countries play a dual role in their economic development. The BRICS group is followed by other developing countries, the so-called prospective States (Vietnam, Indonesia, South Africa, Turkey and Argentina), which put pressure on the group regarding the functioning of markets, global resources and their distribution.

There are also some difficulties regarding the growth model in the BRICS countries. They focus more on GDP growth and less on quality, given the lack of creative minds and incentives to innovate. Investments in technology and education are insufficient, there is a lack of motivation and entrepreneurial spirit, and there is no rational allocation of resources. In addition, corruption affects the economic development of these countries, creating a negative image at the international level, hindering the rational distribution of social resources and exacerbating social conflicts.

Discussion. Despite the current crisis conditions, according to international experts, the current period is the most favorable time for establishing closer ties between the BRICS countries, since the world economy is in a state of fluidity with the convergence of national economic systems, closer integration and rebalancing towards developing economies.

On the one hand, China and the Russian Federation are relatively well-established players in the international arena. Both have a strong position in relations with the developed world, are military powers and have acquired leading roles in global security: they are permanent members of the UN Security Council, have the right of veto and participate in negotiations on the Iranian and North Korean nuclear programs.

Russia is a key player in ensuring energy security, while China influences the international balance of supply and demand, as it is the most populous country in the world.

China and Russia are members of the Shanghai Cooperation Organization, which was founded on June 15, 2001 to ensure regional peace, stability and security. At the same time, both emerging powers put forward individual initiatives, such as the Russian initiative for the Eurasian Economic Community or the Chinese proposal to create an Asian Infrastructure Investment Bank with a credit potential of US \$ 100 billion, competing with the Asian Development Bank at US \$ 165 billion [14].

On the other hand, Brazil, India and South Africa are in search of their own identity and recognition. This explains why the India-Brazil-South Africa (IBSA) dialogue is conducted in parallel with the BRICS structure, each of which has its own specific goals. Two major players, China and Russia, support the aspirations of Brazil, India and South Africa to play a greater role in international organizations such as the United Nations (UN). [15]

BRICS is considered in the literature as one of the most innovative and surprising new elements in the modern governance structure, with a flexible, gradual and evolutionary agenda. In 2013, the Russian Federation proposed a long-term strategy for economic cooperation between the BRICS countries, based on the following areas of cooperation - 
- trade and investment;

- manufacturing and mining industry;

- power engineering;

- transport and logistics;

- agricultural production;

- innovation and technological exchange [16].

The draft strategy also included views on cooperation with international and regional organizations, such as the WTO, the UN.

The last BRICS online summit, held in November 2020, highlighted the participants ' determination to lay the foundations for a new financial world order focused on currencies and the needs of emerging markets.

However, there are several threats to the BRICS initiatives. One of them is the dominant position of the West, for example, in relation to the channels of international finance, trade and transport used for the trade in crude oil, including the pricing system. It may be difficult for the BRICS to find alternatives to the society for international interbank financial transactions [17].

Given the recent economic slowdown in the BRICS countries, the growing uncertainty and vulnerability at the global level, as well as the escalating tensions between West and East, as well as North and South, it is clear that the five partners are looking for a formula for long-term cooperation with mutual benefit.

Conclusions. Although the BRICS were among the countries that helped to revive the world economy in the twenty-first century after the financial crisis, today they are showing a sharp slowdown after a decade of global boom. From 2016 to 2020, the BRICS group showed a growth rate of $5 \%$ per year, which is the worst performance for developing economies in the last decade. It can be assumed that the first rapid stage of BRICS development, during which the economies of the group countries grew by up to $50 \%$ per year, has been completed.

China is in a period of transition from investment-based growth to a more balanced consumption-based model. The Chinese government has the ability to cover losses from bad loans and stimulate the economy. Even if there were some monetary restrictions, the BRICS countries are pursuing a defense policy that includes flexible exchange rates, relatively low debt, and high foreign exchange reserves. The slowdown in China will affect the performance of other developing countries.

The raw material potential of Brazil and India also does not contribute to the growth of the economic potential of these countries today. In the coming years, emerging economies will still grow, but gradually, and this will have a significant impact on the global economy in the long term. Meanwhile, cooperation between emerging Powers plays a vital role in promoting pluralism and balance in foreign policy and reducing their dependence on developed economies. Since each of the BRICS countries has limited power, strengthening cooperation is not only a prerequisite for dealing with the global financial crisis, but also a safe choice for the five countries to grow together in the post-crisis period.

\section{References}

1. H.-J. Chang Kicking away the ladder: Neoliberalism and the 'Real' History of capitalism K.-S. Chang, L. Weiss, B. Fine (Eds.), Developmental politics in transition - The Neoliberal era and beyond, Palgrave Macmillan, Hampshire, United Kingdom (2012), pp. 43-50

2. E.-I. Dumitrescu, C. Hurlin Testing for Granger non-causality in heterogeneous panels Journal of Economic Modelling, 29 (4) (2012), pp. 1450-1460

3. P. Lemieux American and European welfare states: Similar causes, similar effects Cato Journal, 33 (2) (2013), pp. 227-232

4. Kishore, R. et al. (2013). Business Trends 2013: Adapt. Evolve. Transform. [online] London, UK: Deliotte University Press. Available at: http://cdn.dupress.com/wpcontent/uploads/2013/03/2013-SO-Business-Trends_vFINAL-screen1.pdf?d7fccb [Accessed 5 Oct. 2014].

5. Kocourek, A. (2014). Vnitřní a vnější soudržnost zemí skupiny BRICS. In P. Jedlička (Ed.) Sborník recenzovaných příspěvků z mezinárodní konference Hradecké ekonomické dny 2014, II. vol. (1 ed., pp. 11-19). 
6. R. Ulucak Danish, S.U.-D. Khan Determinants of the ecological footprint: role of renewable energy, natural resources, and urbanization Sustain. Cities Soc., 54 (2020), Article 101996,

7. Z. Danish, wang Investigation of the ecological footprint's driving factors: what we learn from the experience of emerging economies Sustain. Cities Soc., 49 (2019),

8. R. Danish, Ulucak How do environmental technologies affect green growth? Evidence from BRICS economies Sci. Total Environ., 712 (2020)

9. M. Aydin The effect of biomass energy consumption on economic growth in BRICS countries: a country-specific panel data analysis Renew. Energy, 138 (2019), pp. 620-627

10. Z. Wang, Q. Bui, B. Zhang The Relationship between Biomass Energy Consumption and Human Development: Empirical Evidence from BRICS Countries (2020), p. 194

11. R. Ulucak, Danish, S.U.D. Khan Does information and communication technology affect $\mathrm{CO} 2$ mitigation under the pathway of sustainable development during the mode of globalization? Sustain. Dev. (2020), pp. 1-11,

12. I. Ozturk Measuring the impact of alternative and nuclear energy consumption, carbon dioxide emissions and oil rents on specific growth factors in the panel of Latin American countries Prog. Nucl. Energy, 100 (2017), pp. 71-81

13. M.A. Destek, A. Sinha Renewable, non-renewable energy consumption, economic growth, trade openness and ecological footprint: evidence from organisation for economic Cooperation and development countries J. Clean. Prod., 242 (2020), Article 118537

14. D. Balsalobre-Lorente, M. Shahbaz, D. Roubaud, S. Farhani How economic growth, renewable electricity and natural resources contribute to CO2 emissions? Energy Pol., 113 (2018), pp. 356-367

15. A. Alvarez-herranz, D. Balsalobre-lorente, M. Shahbaz Energy innovation and renewable energy consumption in the correction of air pollution levels Energy Pol., 105 (2017), pp. 386-397

16. A. Sinha, M. Shahbaz, D. Balsalobre Exploring the relationship between energy usage segregation and environmental degradation in N-11 countries J. Clean. Prod., 168 (2017), pp. $1217-1229$

17. Z. Wang, Danish, B. Zhang, B. Wang The moderating role of corruption between economic growth and CO2 emissions: evidence from BRICS economies Energy, 148 (2018), pp. 506-513, 